\title{
Genetic variability, broad sense heritability and genetic advance studies in bread wheat (Triticum aestivum $\mathrm{L}$.) germplasm
}

\author{
Arshad Jamil ${ }^{1}$, Shahjehan Khan ${ }^{1}$, Obaid Ullah Sayal ${ }^{1}$, Muhammad \\ Waqas $^{2 *}$, Qudratullah ${ }^{3}$ and Shujaat Ali ${ }^{1}$ \\ 1. Department of Plant Breeding and Genetic Gomal University-Pakistan \\ 2. Department of Agricultural Chemistry, The University of Agriculture Peshawar-Pakistan \\ 3. Departments of Soil and Environmental Science Gomal University-Pakistan \\ *Corresponding author's email: waqasgandapur404@gmail.com \\ Citation \\ Arshad Jamil, Shahjehan Khan, Obaid Ullah Sayal, Muhammad Waqas, Qudratullah and Shujaat Ali. Genetic \\ variability, broad sense heritability and genetic advance studies in bread wheat (Triticum aestivum L.) germplasm. \\ Pure and Applied Biology. Vol. 6, Issue 2, pp538-543. http://dx.doi.org/10.19045/bspab.2017.60055
}

Received: $25 / 10 / 2016$

Revised: 06/04/2017

Accepted: 10/04/2017

Online First: 15/04/2017

\section{Abstract}

The experiment was conducted at Faculty of Agriculture, Gomal University D.I.Khan Pakistan during 2013-2014 to estimate genetic diversity, heritability and genetic advances for few characters which relate to yield in bread wheat. Sixty wheat genotypes obtained from NARC, Islamabad worked out in the current research work. The experiment was laid out in (RCBD) having 3 replications. The aspects for recording data included number of tillers plant ${ }^{-1}$, plant height, number of spikelet's spike ${ }^{-1}$, number of grain spike ${ }^{-1}, 1000$-grain weight and grain yield plant $^{-1}$. ANOVA showed significant differences for all the characters studied. The estimates of phenotypic coefficient of variation (PCV) and genotypic coefficient of variation (GCV) were high for grain yield per plant and 1000-grain yield. The remaining traits exhibit moderate to low PCV and GCV estimates. Phenotypic coefficient of variation showed its maximum value for grain yield plant ${ }^{-1}(44.62 \%)$ and the minimum value was reported for number of spikelets spike ${ }^{-1}$ $(12.63 \%)$. The range for genotypic coefficient of variation was $5.11 \%$ for (Number of spiklets spike $^{-1}$ ) to $42.46 \%$ for (Grain yield plant ${ }^{-1}$. The highest heritability estimates were observed for plant height (98.27\%) and highest genetic advance was reported for grain yield (83.22\%). High heritability coupled with high genetic advance for parameters like 1000-grain weight and grain yield plant ${ }^{-1}$ indicated additive genetic effects. The overall results showed that selection should lead to a fast genetic improvement of the material.

Keywords: Wheat; Genotypes; Genetic variability; Heritability; Genetic advance

\section{Introduction}

Wheat (Triticum aestivum L.) is grown as a major cereal in all over the world including Pakistan. Wheat is grown in all continents of the world. Pakistan is ranked in top ten most wheat producing countries of the world. More than $75 \%$ of the forming community is engaged in growing wheat. Wheat 
production during 2012-13 was 24.2 million tones obtained from 8.69 million hectares showing the increase of $3.2 \%$ in area with average yield of $2787 \mathrm{~kg}$ per hectare Government of Pakistan (2012-2013). The success of a breeding programme depends on the presence of genetic variability in a material in hand. To make the heritable improvement in characters, estimation of genetic parameters and index of their transmissibility is required. Heritability estimates provide information about the extent to which a particular character can be transmitted to the successive generations. Knowledge of heritability of a trait thus guides a plant breeder to predict behavior of succeeding generations and helps in making desirable selections. Selection plays an important role in plant breeding for desired traits in crops. Heritability and genetic advance would help the breeders in selection for crop improvement [1]. These two genetic parameters are very important for any breeding program designed for the improvement of crop as heritability indicates the effectiveness of selection whereas the genetic advance predicts the genetic gain in the next generation [2]. Conventional analysis of variance and statistical parameters like phenotypic and genotypic coefficients of variability, heritability and genetic advance have been used to assess the nature and magnitude of variation in wheat breeding material [3]. This research study was performed to gather some valuable information on inheritance and its application in selection of better genotypes of wheat for the development or improvement of cultivars and germplasm.

\section{Materials and methods}

The study was conducted in the research area of Department of Plant Breeding and Genetics, Faculty of Agriculture, Gomal University, Dera Ismail Khan. Pakistan. Sixty bread wheat genotypes were obtained from NARC, Islamabad to conduct the research study. The experiment was carried out in a randomized complete block design having three replications. Plot size was kept $18 \mathrm{~m} \times 5 \mathrm{~m}$ with 60 lines replication ${ }^{-1}$, and each line was kept 5 meter long and $30 \mathrm{~cm}$ apart. Recommended doses of nitrogen and phosphorus were used before and after sowing the crop. Six quantitative traits including number of tillers plant ${ }^{-1}$, plant height, number of spikelets spike ${ }^{-1}$, number of grains spike $^{-1}, 1000$-grain weight and grain yield plant ${ }^{-1}$ were brought under consideration. Data were subjected to analysis of variance [4]. Broad sense heritability $\left(\mathrm{h}^{2}{ }_{\mathrm{BS}}\right)$ was calculated as a ratio of genotypic to phenotypic variance following the formula [5]. The expected genetic advances estimated by the formula described [6]. Genotypic and phenotypic coefficients of variation were calculated for the estimation of variability [7].

\section{Results and discussion}

According to analysis of variance mean squares for traits like number of tillers plant ${ }^{-}$ 1 , plant height, 1000-grains weight and grain yield plant $^{-1}$ revealed highly significant differences (Table 1). The highest heritability estimates were observed for plant height $(98.27 \%)$ while it was the lowest for number of spikelets plant ${ }^{-1}$ $(16.39 \%)$. All the other characters exhibited heritability estimates between these two extremes. Minimum genetic advance was reported in number of spikelets spike $(4.26 \%)$ while the maximum was reported in grain yield plant ${ }^{-1}(83.22 \%)$. Highest values of phenotypic coefficient of variation and genotypic coefficient of variation were reported in grain yield plant $^{-1}$ which was $(44.62 \%)$ and $(42.46 \%)$. Difference between phenotypic and genotypic coefficients of variation ranged from 0.14 to 11.78 which showed comparatively small environmental effect on the expression of characters. 
Table 1. Analysis of variance for different traits studied in wheat genotypes

\begin{tabular}{|l|l|l|l|l|l|l|l|}
\hline $\begin{array}{l}\text { Source of } \\
\text { variation }\end{array}$ & $\begin{array}{l}\text { Degree } \\
\text { of } \\
\text { freedom }\end{array}$ & $\begin{array}{l}\text { Number } \\
\text { of tillers } \\
\text { plant }^{-1}\end{array}$ & $\begin{array}{l}\text { Plant } \\
\text { Height }\end{array}$ & $\begin{array}{l}\text { Number } \\
\text { of spiklets } \\
\text { spike }^{-1}\end{array}$ & $\begin{array}{l}\text { Number } \\
\text { of grains } \\
\text { spike }^{-1}\end{array}$ & $\begin{array}{l}\text { 1000-grain } \\
\text { weight }\end{array}$ & $\begin{array}{l}\text { Grain yield } \\
\text { plant }^{-1}\end{array}$ \\
\hline Varieties & 59 & $12.56^{* *}$ & $953.38^{* *}$ & $8.87^{*}$ & $454.05^{*}$ & $403.55^{* *}$ & $170.74^{* *}$ \\
\hline Rep & 2 & 1.16 & 0.49 & 0.37 & 2.62 & 0.16 & 2.39 \\
\hline Error & 118 & 5.04 & 5.55 & 5.59 & 5.41 & 6.02 & 5.75 \\
\hline
\end{tabular}

$* *=$ Significant at $1 \%$ probability level and $*=$ Significant at $5 \%$ probability level

\section{Number of tillers plant ${ }^{-1}$}

Highly significant variation was recorded according to statistical analysis of variance among the accessions (Table 1). According to the results the range was 8.87 and the mean value was 9.88 tillers plant $^{-1}$ (Table 2 ). Number of tillers per plant is a yield related trait, as it is directly related with number of spikes plant ${ }^{-1}$. Thus, greater number of tillers per plant will ensure greater grain yield [8]. The value of genotypic coefficient of variation was $16.02 \%$ and that of phenotypic coefficient of variation was $27.80 \%$ (Table 3). High magnitude difference (GCV) and (PCV) suggests the more participation of environment in the expression of character [9]. Also found the same results. Heritability percentage was observed $33.21 \%$ while the expected genetic advance was $19.02 \%$ (Table 4). The results for heritability estimates are in line with [10]. Who also recorded medium heritability estimates for tillers number plant $^{-1}$ in bread wheat.

Table 2. Mean and Range for different traits studied in wheat genotypes

\begin{tabular}{|c|c|c|c|c|c|c|}
\hline $\begin{array}{l}\text { Source of } \\
\text { variation }\end{array}$ & $\begin{array}{l}\text { Number of } \\
\text { tillers plant }^{-1}\end{array}$ & $\begin{array}{l}\text { Plant } \\
\text { Height }\end{array}$ & $\begin{array}{l}\text { Number of } \\
\text { spiklets spike }^{-1}\end{array}$ & $\begin{array}{l}\text { Number of } \\
\text { grains spike }^{-1}\end{array}$ & $\begin{array}{l}\text { 1000-grain } \\
\text { weight }(g)\end{array}$ & $\begin{array}{l}\text { Grain yield } \\
\text { plant }^{-1}(\mathrm{~g})\end{array}$ \\
\hline Mean & 9.88 & 112.00 & 20.47 & 52.06 & 36.05 & 17.47 \\
\hline Maximum & 14.4 & 152.2 & 24.2 & 79.8 & 76.8 & 35.4 \\
\hline Minimum & 5.53 & 78.4 & 17.6 & 24.4 & 13.30 & 4.36 \\
\hline Range & 8.87 & 73.80 & 6.60 & 55.40 & 63.50 & 31.04 \\
\hline
\end{tabular}

Table 3. Phenotypic and genotypic coefficient of variation for different traits studied in wheat genotypes

\begin{tabular}{|c|c|c|c|c|c|c|}
\hline Source of variation & $\begin{array}{l}\text { Number } \\
\text { of tillers } \\
\text { plant }^{-1}\end{array}$ & $\begin{array}{l}\text { Plant } \\
\text { Height }\end{array}$ & $\begin{array}{l}\text { Number of } \\
\text { spiklets } \\
\text { spike }^{-1}\end{array}$ & $\begin{array}{l}\text { Number } \\
\text { of grains } \\
\text { spike }^{-1}\end{array}$ & $\begin{array}{l}\text { 1000-grain } \\
\text { weight }\end{array}$ & $\begin{array}{l}\text { Grain yield } \\
\text { plant }^{-1}\end{array}$ \\
\hline $\begin{array}{l}\text { Phenotypic coefficient of } \\
\text { variation }(\%)\end{array}$ & 27.80 & 16.01 & 12.63 & 23.91 & 32.64 & 44.62 \\
\hline $\begin{array}{l}\text { Genotypic coefficient of } \\
\text { variation }(\%)\end{array}$ & 16.02 & 15.87 & 5.11 & 23.49 & 31.92 & 42.46 \\
\hline Difference & 11.78 & 0.14 & 7.52 & 0.42 & 0.72 & 2.16 \\
\hline
\end{tabular}


Table 4. Heritability and genetic advance for different traits studied in wheat genotypes

\begin{tabular}{|c|c|c|c|c|c|c|}
\hline Source of variation & $\begin{array}{l}\text { Number of } \\
\text { tillers plant }^{-1}\end{array}$ & $\begin{array}{l}\text { Plant } \\
\text { Height }\end{array}$ & $\begin{array}{l}\text { Number of } \\
\text { spiklets } \\
\text { spike }^{-1}\end{array}$ & $\begin{array}{l}\text { Number } \\
\text { of grains } \\
\text { spike }^{-1}\end{array}$ & $\begin{array}{l}\text { 1000-grain } \\
\text { weight }\end{array}$ & $\begin{array}{l}\text { Grain yield } \\
\text { plant }^{-1}\end{array}$ \\
\hline Heritability & 33.21 & 98.27 & 16.39 & 96.51 & 95.66 & 90.53 \\
\hline Genetic Advance & 19.02 & 32.41 & 4.26 & 47.53 & 64.32 & 83.22 \\
\hline
\end{tabular}

\section{Plant height (cm)}

Analysis of variance showed highly significant differences for plant height as shown in Table 1. The variation showed a range of $73.80 \mathrm{~cm}$ and the mean value for plant height was $112 \mathrm{~cm}$ (Table 2). Higher plants generally considered good to obtain substantial amount of straw but plant height is much helpful for improving grain yield [11]. Genotypic coefficient of variation (GCV) and phenotypic coefficient of variation (PCV) values were $15.87 \%$ and $16.01 \%$ respectively (Table 3 ). Very small difference between (PCV) and (GCV) indicates minor effect of environment. The value of heritability was $98.27 \%$ and expected genetic advance was $32.41 \%$ (Table 4). High heritability indicates more genetic control or less environmental effect on this trait [12].

Number of spikelets spike ${ }^{-1}$

Analysis of variance showed highly significant variation for spikelets spike ${ }^{-1}$ among the accessions (Table 1). This is an important yield enhancing trait because increased spikelets will increase number of grains and eventually grain yield will automatically be increased. The range of variation for number of spikelets spike ${ }^{-1}$ was 6.60 and the mean value was 20.47 (Table 2). Genotypic coefficient of variation (GCV) value was $5.11 \%$ and the phenotypic coefficient of variation (PCV) value was $12.63 \%$ (Table 3). [13]. Also found same lower values of (PCV) and (GCV). Heritability value for this parameter was $16.39 \%$ and expected genetic advance was $4.26 \%$ (Table 4). Moderate to low values of heritability and genetic advance were also reported by [14].
Number of grains spike ${ }^{-1}$

Analysis of variance showed highly significant difference for this parameter among the accession as shown in Table 1. This trait is also an important for yield point of view. It depends upon various other traits like spike length, spikelets per spike and spike density. A greater number of grains per spike would only be useful if they are healthy and not shrunken having adequate weight [15]. The range according to the mean data was 55.40 and the mean value for number of grains spike ${ }^{-1}$ was 52.06 (Table 2). Genotypic coefficient of variation (GCV) and phenotypic coefficient of variation (PCV) values were $23.49 \%$ and $23.91 \%$ respectively (Table 3). Moderate values of (PCV) and (GCV) showed minor difference which indicates less environmental influence. The heritability value was $96.51 \%$ and the value of expected genetic advance was $47.53 \%$ (Table 4). High heritability along with moderate value of genetic advance was also obtained by [16].

\section{0-grain weight}

1000-grain weight showed highly significant difference according to the analysis of variance among all the accessions (Table 1). The range was noted as $63.50 \mathrm{~g}$ and the mean value for 1000 -grains weight was $36.05 \mathrm{~g}$ (Table 2). The values of genotypic coefficient of variation (GCV) and phenotypic coefficient of variation (PCV) were $31.92 \%$ and $32.64 \%$ respectively (Table 3). [16]. also obtained moderate values of (PCV) and (GCV). Heritability estimates was $95.66 \%$ and expected genetic advance was $64.32 \%$ (Table 4). High heritability accompanied with high expected genetic advance indicates that most likely 
the heritability is due to additive gene effects and selection may be effective in early generations for this trait. Similar findings have been reported by [17].

\section{Grain yield plant $^{-1}(\mathrm{~g})$}

Analysis of variance showed that this character possessed highly significant variations among all the genotypes (Table 1). Range of this variability was 31.04 and the mean value was $17.47 \mathrm{~g}$ (Table 2). Value of the genotypic coefficient of variation (GCV) was $42.46 \%$ while the value of phenotypic coefficient of variation (PCV) was $44.62 \%$ as shown in Table 3 . The heritability value for this parameter was 90.53\% and expected genetic advance was $83.22 \%$ (Table 4). High heritability accompanied with high genetic advance shows that the heritability is due to additive genetic control and selection may be effective in early generations for these traits. [18]. Also found same results for this. Similar findings have been reported by [18].

\section{Conclusion}

The overall results confirmed the presence of significant amount of variation which makes this material suitable for breeding purpose. High heritability along with high genetic advance for all studied traits except number of spikelets spike ${ }^{-1}$ suggested that the selection for these characters can be fruitful for the improvement of grain yield and its components in wheat.

\section{Authors' contributions}

Conceived and designed the experiments: A Jamil \& S Jahan, Performed the Experiments: A Jamil \& S Ali, Analyzed the Data: WK Gandapur, Contributed reagents/ materials/ analysis tools: QU Khan \& OU Siyal, Wrote the paper: A Jamil.

\section{Acknowledgments}

The author is thankful to Mr. Muhammad Waqas Khan Gandapur Department of Agricultural Chemistry Faculty of Nutrition Sciences, The University of Agriculture Peshawar Pakistan for Statiscal analysis and help in scientific writing of this manuscript.

\section{References}

1. Asghar M \& Mehdi SS (1999). Variability for grain yield, its components and quality traits in a sweet corn population. Pak J Biol Sci 2(4): 1366-70.

2. Najeeb S, Rather G, Parray V, Sheikh FA \& Razvi SM (2009). Studies on genetic variability, genotypic correlation and path coefficient analysis in maize under high altitude temperate ecology of Kashmir. Maize Genetics Cooperation Newsletter 83: 95-97.

3. Cheema N, Ma M, Mian V, Ihsan V, Rabbani G \& Mahmood A (2006). Studies on variability and some genetic parameters in spring wheat. Pak J Agri Sci 43(1-2).

4. Steel RGD, Torrie JH \& Dickey A (1997). Principles and Procedure of Statistics. A Biometrical Approach. Mc Graw Hill, Book Co. New York. USA 2nd Inter. Ed pp 663.

5. Falconer D (1989). Introduction to Quantitative Genetics. Logman Scientific and Technical, Logman House, Burnt Mill, Harlow, Essex, England 3rd Ed.

6. Allard R W. (1960). Principles of plant breeding. John Wiley and Sons, New York.

7. Singh RK \& Chaudhary V (1985). Biometric Methods in Quantitative Genetic Analysis. Kalyani Publishers, New Delhi, India.

8. Firouzian A, Khan S \& Ali Z (2003). Genetic variability and inheritance of grain yield and its components in wheat. Pak J Agri Sci 40(3-4).

9. Kalimullah S, Khan J, Irfaq $M$ \& Rahman, HU (2012). Genetic variability correlation and diversity studies in bread wheat (Triticum aestivum L.) germplasm. J Ani Pl Sci 22(2): 330-333. 
10. Alvi MB, Rafique M, Tariq MS, Hussain A, Mahmood T \& Sarwar M (2003). Character association and path coefficient analysis of grain yield and yield components in maize (Zea mays L.). Pak J Biol Sci 6(2): 136-38.

11. Fehr WR (1987). Principles of Cultivar Development, Theory and Techniques. Macmillan Publishing Co., New York. Vol. 1.

12. Ali YBM, Atta J, Akhter P, Monneveux \& Lateef Z (2008). Genetic variability, association and diversity studies in wheat (Triticum aestivum L.) germplasm. Pak J Bot 40(5): 20872097.

13. Gulnaz S, Khan SH, Shahzad M, Ashfaq M \& Sajjad M (2012). Genetic Evaluation of Spring Wheat (Triticum aestivum L.) Germplasm for Yield and Seedling Vigor Traits. J Agric Soc Sci 8(4): 123-128.

14. Salman S, Khan SJ, Khan J, Khan RU \& Khan I (2014). Genetic variability studies in bread wheat (triticum aestivum L.) accessions. $P J$ Agric 27(1): 1-7.

15. Munir M, Chaudhary MA \& Malik TA (2007). Correlation Studies among Yield and its Components in Bread Wheat under Drought Conditions. Int J Agri and Bio 1560- 8530/2007/09-2287-290.

16. Sharma AK \& Garg DK (2002). Genetic variability in wheat (Triticum aestivum L.) crosses under different normal and saline environments. Annals Agric Res 23(3): 497-499.

17. Johnson HW, Robinson HF \& Comstock RE (1955). Estimates of genetic and environmental variability in soybean. Agron J 47: 314-318.

18. Pakistan Economic Survey. 2011-12. Economic advisor's wing, finance division, government of Pakistan, Islamabad. 